\title{
Intergenerational Education to Enhance Sustainable Community Development
}

\author{
Nives Ličen \\ University of Ljubljana, Faculty of Arts, SLOVENIA \\ Aleksandra Šindić \\ University of Banja Luka, Faculty of Philosophy, BOSNIA AND HERZEGOVINA \\ Jurka Lepičnik Vodopivec \\ University of Primorska, Faculty of Education, SLOVENIA \\ Klara Kožar Rosulnik \\ Research Centre of the Slovenian Academy of Science and Arts, SLOVENIA \\ Slovenian Migration Institute
}

Received: 12 February 2021 - Accepted: 13 April 2021 • Published Online: 27 May 2021

\begin{abstract}
The article outlines the emergent cooperation between generations in the local environment. The aim of the research was to identify the key characteristics of learning ecologies that may be used to promote new practices. The theoretical framework was constructed through the concepts of learning ecology, community education, and postformal education. A qualitative research approach was used. Data was collected by means of 10 individual and one focus group interviews. The research revealed that the networks of different actors in the local community are effective approaches for developing intergenerational practices. It is important to connect different types of knowledge (intangible cultural heritage, local knowledge and scientific knowledge, social and emotional knowledge), skills and values, as well as different groups and organizations in the local environment to act and learn together.
\end{abstract}

Keywords: community education, learning ecology, local community, sustainable development.

\section{Introduction}

The complexity of the $21^{\text {st }}$ century leads to a search for innovative practices that can respond to the social and economic challenges of the ecological crisis. A number of projects that explore the options for developing new social practices are underway and various nongovernmental organizations, e.g., ECOLISE, the European network for community-led initiatives, have emphasized the need for social innovation. The presented research was based on the thesis that sustainable development and community well-being require the education of all generations and, therefore, new intergenerational connections are sought. A new ethic linked to ecological justice is emerging in the wake of the posthumanist turn (Häggström, 2017; Smith, 2019). The aim

(C) Authors. Terms and conditions of Creative Commons Attribution 4.0 International (CC BY 4.0) apply. Correspondence: Klara Kožar Rosulnik, Research Centre of the Slovenian Academy of Science and Arts, Slovenian Migration Institute, Ljubljana, SLOVENIA. E-mail: klara.kozar-rosulnik@zrc-sazu.si. 
was to explore the factors that promote the development of innovation in community-based environmental education. The conceptual framework for reflection on intergenerational learning consisted of postformal education, learning ecologies, community well-being and intergenerational education.

\section{Conceptual framework}

\subsection{Learning ecologies and postformal education}

Educational organizations are opening up to the environment and joining together in educational and learning networks. To reflect on their work, they use the concept of postformal education (Gidley, 2016) and posthumanism (Braidotti, 2013), which allows the interpretation of learning with a focus on interpersonal relationships and relationships between humans and nonhumans (Taylor \& Hughes, 2016). Higgins (2016) explored the ecologies of relationships, which include those between humans, and relationships between humans and other-than-human matter, i.e., plants, animals, rivers, mountains, space. They also include more-than-human relationships, i.e., relationships with what is beyond humans. The ecology of relationships encompasses all individuals' relationships with humans and non-humans (e.g., street graffiti, which serves the role of an educator), with learning taking place in all relationships. Local culture is created in relationships, as is a sense of place (Jubas \& Lenters, 2019; Fenwick \& Edwards, 2017). This is important for the presented research as intergenerational ecological education is intended to encourage attachment to a place.

Another concept that has emerged in addition to the ecologies of relationships is the learning ecology concept, which incorporates all learning processes that create complex learning environments (Barnett \& Jackson, 2020; Yamagata-Lynch, 2010) and multiple complex systems of interaction. Therefore, it is perfectly legitimate to explore the cooperation between different actors of formal, non-formal, and informal education as there is a flow of knowledge, skills, values, attitudes, and affects between environments. Since all learning activities within an environment form a learning ecology, it is important to connect different types of learning and different learning outcomes (e.g., knowledge, practical wisdom, wisdom, skills, virtues), as well as groups of people and institutions.

Postformal education and posthumanism challenge traditional concepts, such as identity. Identity formation is a persisting entity and is a culturally and spatially embedded process, which is why the term "liquid learners" has emerged to refer to learners who are formed continuously. In posthumanism, ecological views of humans come together in movements that do not believe humans occupy a central position in the world, whereas anthropocentrism was a human-centered viewpoint that regarded humans as actors that impact the development of their environment. Industrial society has brought development - based on rationality and power - to the forefront, despite the fact that humans are not the only ones living on the planet and should consider all other living and non-living things (Taylor \& Hughes, 2016). Posthuman ecologies (Braidotti \& Bigual, 2018) expose human agency and moral responsibility in connection with the contemporary paradox of non-human development. Responses to many challenges also need to be sought in education. The responses will be reflected as the changed paradigms of learning that Gidley (2016) referred to as postformal education, which responds to the complexity of our time. The existing education model was developed to educate people for industrial and colonial expansion, and modern education is expected to prepare people for global uncertainty, complexity and changes. It is therefore imperative to develop creativity, flexibility and participation, as well as resilience and, in doing so, connect all learning environments, i.e. all environments where people learn, into common learning ecologies. 


\subsection{Community well-being and community education}

Community well-being is defined as a "state in which the needs and desires of a community are fulfilled” (Lee, Kim \& Philips, 2015: 2; Martinez, Verplanke \& Miscione, 2017: 386387). This includes economic, social, environmental and cultural needs. An alternative definition links well-being to the quality of life. However, at a time of intense technoscientific transformation, when it is not known where the development in an industrially polluted environment is heading for, it is necessary to think critically about the ecological crisis (Latouche, 2018), the extreme complexity and the weak sense of belonging that affect community well-being. Guattari (2000) sought the answer to this problem in ecological philosophy, i.e., a philosophy of ecological harmony. Ecosophy is an ethico-political articulation between ecological registers: the environment, social relations and human subjectivity. An ecosophical issue is that of the production of human existence itself in new historical contexts, and therefore strives for the development of specific practices that will modify the ways in which we live as families, in a local community or at work. Mental ecosophy will lead us to reinvent the relation of the subject to the body, the passage of time, the mysteries of life and death (while searching for conformism, standardisation, manipulation through advertising, etc.). As pointed out by Guattari (2000), to exist it is not enough only to think (cogito), as one does not only exist in thoughts, but the subject is created in many areas (Higgins, 2016; Gidley, 2016). Guattari (2000, p.36) used the term components of subjectification, which are the elements of all types of education. It is necessary to kick the habits, routines, and the 'sedative discourse' in order to be able to apprehend the world and the production of human existence through the points of view of the three ecologies. Intergenerational education has the capacity to explore routines. Intergenerational education and sustainable development are viewed as a complex and integrated practice that is embedded in a particular social and cultural context. All the elements are interconnected and act as a whole that is aimed at developing community well-being. Social well-being includes the following: affective elements such as belonging, inclusion, contribution and trust, as well as social elements such as solidarity and common goals. All these elements can be impacted through education. All events or practices take place in a context that includes history (personal history, community history), as well as present events and future projections.

An important concept for community education is the concept of social empowerment of all groups through connectivity and inclusion (Anderson, 2017). Intergenerational education as part of community education is an extensive and inclusive education, defined by local narratives, non-hierarchical relationships, progressive and emancipatory dynamics. These ideas are important because, in the light of a sustainable future, transformative and expansive learning is required to develop mutual trust, solidarity and reciprocity. Community education promotes commitment to the common good and to caring relationships, all of which is part of community well-being. In its early beginnings, community education in local environments also became linked to religion as an integral part of culture. However, since contemporary religiosity "individualizes" and no longer constitutes a binding element, a different kind of connection is important, such as being connected through joint efforts to save the environment.

Sustainable development can be considered in broader and narrower contexts. A policy framework set by the United Nations is a very broad context. The broad goals of the 2030 Agenda embody a common global vision. They are a universal set of goals for which the UN member states are expected to strive, however, more culturally specific goals that are relevant to the local environments need to be created for each environment. In doing so, it is also important to develop environmental ethics through education (Weldemariam, 2017). Intergenerational education for sustainable development is a dynamic and rapidly evolving practice that includes a new perspective on education and seeks to educate all generations to take responsibility for cocreating the future. Various institutions are involved in the organization of education for sustainable development: universities, adult education centers, primary schools, cultural 
institutions, societies and also preschools. Parents and grandparents are willing to participate in children's projects, and schools can thus operate as a factor that contributes to the awareness of the importance of environmental protection in the local environment.

\section{Research problem and research questions}

The empirical part of the research was focused on examining cases through which community learning networks are developed in the local environment with regard to the implementation of environmental intergenerational education practices. Environmental education in preschools and schools in Slovenia is relatively well developed, environmental education for adults in the local environment, however, is developed to a lesser degree. The aim was to examine how selected interviewees assess key factors in the emergent practices that create intergenerational learning ecologies and involve children, adults and older adults.

In the community education network, preschools and schools hold a special place on account of (a) the emotional bond between generations and the mutual attachment of adults and children, and (b) intergenerational education and the transfer of knowledge within the network from older to younger members, and vice versa. In fact, research has shown that children in preschools and schools are aware of the importance of caring for the environment (Engdahl, 2015). The findings that new strategies and networks are being developed in community education have been corroborated by other studies (Clover, Jayme, Hall \& Follen, 2013; Fazey, 2017; Kaplan, Sanchez \& Hoffman, 2017; Philips \& Wong, 2017). There has, however, been relatively little research into how people assess intergenerational learning as part of community education and the formation of learning ecologies. questions:

The research presented in this paper was focused on the following two research

What factors do research participants consider important for the development of intergenerational community education?

How do research participants experience the affective elements of intergenerational learning in the context of community well-being?

\section{Methodology}

Qualitative research (Creswell \& Plano Clark, 2017; Flick, 2019) was used, in particular narrative methods, as the aim was to learn about the way participants judge the characteristics of good practices related to innovation in intergenerational learning in a local community. The aim was to study a contemporary phenomenon that is part of social developments over which we have no visible influence and whose course we are unable to control, and therefore a qualitative research paradigm was chosen. A further aim was to examine the process from different angles (Yin, 2018). In the real world, the phenomenon and the context are not separable, and therefore several sources that allow triangulation of data sources were used in the research.

Empirical data was collected in Slovenia, a country with a population of two million, which has a well-expanded network of preschools, schools and universities of the third age, as well as a well-functioning system of non-governmental organizations (societies). Individual partially structured interviews and a focus group were used for the collection of data, which took place between 2019 and 2020. Research preparations (2019) included an analysis of forty websites of societies, schools and preschools, movements that are involved in intergenerational learning for sustainable development and bring together various actors (e.g., an eco-school/eco-preschool, Institute for Spatial Policies (IpoP), etc.) in community education. Representatives of all the 
practices were chosen and in-depth interviews (a total of ten) on intergenerational learning in a local environment were conducted with them during the next research stage.

\subsection{Participants}

The interviewees that took part in the research were from different backgrounds and different regions of Slovenia. They were selected systematically as individuals involved in different organizations following the aforementioned analysis of organizations' activities based on their websites. All the interviewees had experience with intergenerational learning. A total of nine interviews were conducted first, followed by a follow-up interview with an expert on community education and older adult education.

Table 1. List of interviewees, $\mathrm{F}=$ female; $\mathrm{M}=$ male

\begin{tabular}{|l|l|l|l|}
\hline $\begin{array}{l}\text { Interview } \\
\text { Number }\end{array}$ & Interviewees & Sex and Age & $\begin{array}{l}\text { Educational } \\
\text { Attainment }\end{array}$ \\
\hline 1 & $\begin{array}{l}\text { Educator/community workshop leader, study } \\
\text { circle mentor }\end{array}$ & F, 39 & BA \\
\hline 2 & President of the local Anbot society, Piran & F, 70 & BA \\
\hline 3 & $\begin{array}{l}\text { Member of the local Housewives' Society, } \\
\text { Planina }\end{array}$ & F, 62 & Secondary school \\
\hline 4 & Mother of one of the girls in the preschool & F, 34 & MA \\
\hline 5 & Grandfather & M, 73 & Secondary school \\
\hline 6 & Preschool teacher & F, 32 & MA \\
\hline 7 & Teacher & F, 48 & MA \\
\hline 9 & School head teacher & M, 45 & MA \\
\hline 10 & Mentor at the Slovenian Third Age University & F, 53 & MA \\
\hline
\end{tabular}

The interviews lasted from 45 minutes to 1 hour and were conducted to learn more about the phenomena from the different angles of actors in the local environment.

The interviews were followed by a focus group, which was conducted in November 2020 with five participants in older adult education. The focus interview was conducted through Zoom and lasted 90 minutes.

Table 2. List of focus group participants, $\mathrm{F}=$ female; $\mathrm{M}=$ male

\begin{tabular}{|l|l|l|}
\hline \multicolumn{1}{|c|}{ Focus Group Participant } & \multicolumn{1}{|c|}{ Sex and Age } & \multicolumn{1}{|c|}{$\begin{array}{c}\text { Educational } \\
\text { Attainment }\end{array}$} \\
\hline Ana & F, 69 & Secondary school \\
\hline Beti & F, 74 & MA \\
\hline Cecilija & F, 62 & MA \\
\hline Črt & M, 67 & MSc \\
\hline Dominika & F, 80 & Secondary school \\
\hline
\end{tabular}

\subsection{Data analysis}

The interviews were transcribed and analyzed using the content analysis method with two-step coding. All the interview transcripts were reviewed in order to become familiar with the material as a whole. Thereafter, coding and categorization work began. Later, data were organized into themes. The interview analysis took place within a conceptual framework: concepts of learning ecology, community education, and postformal education. 


\section{Results and discussion}

The findings were thematized as (a) the connection between processes, actors and types of knowledge, (b) transformative learning, (c) strong communities, and (d) intergenerational contact zones. The table below shows the formation of categories and themes.

Table 3. Themes, categories and interview quotes

\begin{tabular}{|c|c|c|}
\hline Themes & Categories & Examples of Interview Quotes \\
\hline $\begin{array}{l}\text { Connection between } \\
\text { processes, actors and } \\
\text { types of knowledge }\end{array}$ & $\begin{array}{l}\text { Societies as a part of learning } \\
\text { ecologies } \\
\text { Connectivity: multiple knowledge } \\
\text { systems } \\
\text { Innovation in connecting } \\
\text { Participative learning/active } \\
\text { participation } \\
\text { Action learning }\end{array}$ & $\begin{array}{l}\text { Our society makes sure that } \\
\text { children are involved in the } \\
\text { preparation of exhibitions on } \\
\text { healthy eating. We also hold } \\
\text { workshops in schools. [Interview 1] } \\
\text { We put on a theatrical play about } \\
\text { how people used to eat more } \\
\text { healthily in the past. And about } \\
\text { drinking water... Younger and older } \\
\text { people would spend time together, } \\
\text { the less learned and the more } \\
\text { learned. [Interview 3] } \\
\text { As part of projects, we worked with } \\
\text { an ethnologist who guided our work } \\
\text { with professional knowledge. She is } \\
\text { a university researcher. [Interview } \\
\text { 3] }\end{array}$ \\
\hline $\begin{array}{l}\text { Transformative learning } \\
\text { (changing attitudes and } \\
\text { habits) }\end{array}$ & $\begin{array}{l}\text { Ecosocial learning in changing } \\
\text { practices } \\
\text { Relationship-based learning } \\
\text { Becoming (continuous knowledge } \\
\text { and identity construction) } \\
\text { Environmental programmes and } \\
\text { changing habits } \\
\text { Institutions promote better learning } \\
\text { and transformation } \\
\text { Non-formal education }\end{array}$ & $\begin{array}{l}\text { Education is important in creating } \\
\text { new habits; habits need to be } \\
\text { changed. For example, separating } \\
\text { waste. Habits related to food, } \\
\text { however, are harder to change. } \\
\text { [Interview 6] } \\
\text { My best environmental education } \\
\text { took place in relationships with } \\
\text { others, often younger people. I do } \\
\text { read a lot, but you learn most in a } \\
\text { relationship with others when you } \\
\text { work on something together. } \\
\text { [Interview 9] }\end{array}$ \\
\hline Strong communities & $\begin{array}{l}\text { Inclusivity } \\
\text { Planned creation of inclusive } \\
\text { communities } \\
\text { Cohesiveness } \\
\text { Community resilience } \\
\text { Educating parents and teachers } \\
\text { Mutual respect } \\
\text { Sense of belonging } \\
\text { Feeling of safety } \\
\text { Well-being }\end{array}$ & $\begin{array}{l}\text { Our school organizes many } \\
\text { educational meetings, including } \\
\text { environmental ones. The problem, } \\
\text { however, is how to animate those } \\
\text { parents who don't want to join in in } \\
\text { the first place. [Interview 7] }\end{array}$ \\
\hline
\end{tabular}




\begin{tabular}{|l|l|l|}
\hline $\begin{array}{l}\text { Intergenerational contact } \\
\text { zones }\end{array}$ & $\begin{array}{l}\text { Shared places } \\
\text { Issues of local (public) concern } \\
\text { Connected generations } \\
\text { Multiple generations of children, } \\
\text { adults and older adults } \\
\text { Potential intergenerational } \\
\text { engagement }\end{array}$ & $\begin{array}{l}\text { The botanical garden was one such } \\
\text { shared space, but it can also be a } \\
\text { library or a park. Places like this all } \\
\text { have the potential for meetings. } \\
\text { [Focus Group] }\end{array}$ \\
& $\begin{array}{l}\text { We need to make people more } \\
\text { familiar with environmental issues. } \\
\text { The older generation should also be } \\
\text { included. [Interview 5] }\end{array}$ \\
& $\begin{array}{l}\text { Innovative practices } \\
\text { Joyful }\end{array}$ & \\
\hline
\end{tabular}

\subsection{Connection between processes, actors and types of knowledge}

Intergenerational strategies are important for the promotion of learning among all people. In our education system, everything takes place separately according to age. The groups are divided by individual years. We live separately. We need to meet somewhere. We need to organize some activities that bring together the older and the younger generations. [Focus Group]

The research participants emphasized the importance of opportunities for connections that allow learning. Community education that societies, universities of the third age, preschools, and schools are a part of brings together various organizations to benefit all generations. As part of this, organizations cooperate and impact one another. Preschools connecting with other actors of formal and non-formal education in a community-based learning network (or a local learning ecology) prompts reflection on the importance of parents' cooperation with preschools or schools. The connection of actors in a joint complex network also creates more opportunities for intergenerational education.

Societies are an important part of learning ecologies. Those societies that are important actors in their respective local environments also attach great importance to education for sustainable development. The interviews revealed that, when non-formal education for sustainable development is organized, all of them follow learning strategies that provide an experience (experiential learning, action learning, participatory action research), whilst also stimulating creativity, activity and critical thinking (photovoice, storytelling). All aspects of a person (physical, spiritual, cognitive and emotional) need to be addressed in education, hence integrative approaches are used.

It has been noted that in community education for sustainable development/environmental protection, various strategies (study circles, lectures and workshops, conferences, project work, the use of films and artistic approaches) are used that allow transformative learning, the results of which are changed thinking, attitudes, views, emotions this is the case both in Slovenia and other countries. Transformative learning that takes place in relation to resolving water conflicts (Azeiteiro, Leal \& Aires, 2018) leads to the changing of views. In Slovenia, commonly used strategies involve art in connection with local societies (e.g., the Anbot society), cultural heritage (the Housewives' Society) and the introduction of innovative projects (Slovenian Third Age University).

The Slovenian Third Age University has been focusing on innovative learning with all its educational formats and innovative social practices in the field of "professional" volunteering based on purposive education and volunteering in 
culture (cultural mediators in museums), Personal Town Tours having transformed older learners into self-confident researchers, tourist guides, authors of texts, teachers, enlightened citizens and participants in radio programs and exhibitions, and CINAGE [European Cinema for Active Ageing], which resulted in older learners learning significantly about active ageing and shooting short featured films in cooperation with younger filmmakers. [Interview 10]

The analysis of interviews suggests that many groups and organizations that participate in projects that are recognized as effective in their environment created learning ecologies, although the interviewees did not use this particular term to refer to their practices.

The changes needed for environmental protection require making decisions that relate to responsibility, commitment and a willingness to act. Knowledge (scientific knowledge) alone does not suffice - socio-emotional knowledge, active wisdom or practical wisdom with ethical components related to the environment (local knowledge) and developed socio-cultural practices are much desired elements. This is consistent with the research findings from various other environments (Röttger-Rössler \& Slaby, 2018). The interviewees pointed out that all types of knowledge need to be combined for sustainable development. Parents play an important role in integrating different types of knowledge and organizations. They feel an intense emotional bond for children and are therefore willing to participate in some projects that they would not be keen on joining if their children were not involved. Thus, parents' motivation for participation in such projects increases. This is a case of dual embeddedness into the environment: through the relationship with children and through local knowledge, which is viewed as intangible cultural heritage and has a motivational effect on different groups (e.g., local older adults who are attached to cultural heritage through their memories). Different types of knowledge form a rhizomatic connection, which is driven precisely by the emotional (relational and affective) connection between children and adults.

\subsection{Transformative learning: Preschools and schools as institutions that promote transformative environmental education}

Preschool teachers, teachers, parents and grandparents cooperate within the community in forming new habits, which takes place as transformative learning. An example of this is sustainable mobility projects (e.g., the White Bunny project) that promote exercise and walking. It has been noted that the kind of project work that people are personally involved in is particularly important. When adults (parents) and older adults (grandparents) accompany children to a preschool or school, they help children develop the habit of walking and, in doing so, physical activity also becomes an important part of their lives and a habit. If the first process is viewed as intentional education, the second is considered transformative learning. As pointed out in the focus group, transformation happens when different views are confronted.

The complex issue of sustainable development cannot be solved only in homogeneous groups. Such [homogeneous] groups agree with one another and are not encouraged to change, for example, their views. Each group understands the problem in its own way but nothing happens. It is necessary to make sure that different voices are heard, and then a new understanding is gained so that things can change. The whole lifestyle needs to change. [Focus Group]

Some other examples of introducing innovations that encourage new practices and transformative learning in the environment that were mentioned in the interviews are: encouraging environmental awareness and waste sorting, sensory gardens, and the Open Learning Environment for All Generations project (2019). This project is based on the idea of a preschool in a small rural town working with other partners to contribute new ideas for the development of the rural area and the development of green tourism in accordance with the natural capacities of 
the area in question. In this case, the open learning environment will be created in three locations and will be intended for all generations to which the education of preschool teachers, parents and local residents will be linked. The educational topics form the pedagogy of heritage model and include the following: the attitude to the environment and the potentials of heritage, green tourism through the interpretation of tradition, forests, and the "intelligence" of nature. In this project, the preschool is a part of innovations in the local environment, a part of social connections and through its activities an important part of the community, which is also the case in other environments, as noted by Stoknes (2015).

In many preschools in Slovenia, the Eco-School/Eco-Preschool project is developed as a way of life. As part of these projects, parents and grandparents work with children and preschool teachers, preparing and holding eco-workshops to promote healthy lifestyle habits. The workshops are prepared in accordance with preschool education programs. Some are related to art-based approaches, while others relate to forest pedagogy. These workshops have also been found to have an impact on the whole community as ideas spread through children and parents into the environment. In this way, emancipative psycho-social capital (i.e., mutual trust) is developed. Similar examples of cooperation can be found in the field of forest pedagogy. Outdoor education is being developed and a network of forest preschools and schools, which also organize various environmental workshops, is being set up in the local environment. Another example of cooperation in the local environment is that between preschool children and members of the Slovenian Third Age University, as well as museums or libraries. For example, older adult volunteers who are members of the Third Age University participate in workshops for children in museums and local libraries. Intergenerational cooperation promotes the transfer of knowledge. The various examples presented suggest that preschools and schools are important factors in establishing social connections between social organizations, that they use practices that promote changes aimed at environmental protection and environmental education, and that they impact transformative learning in the environment.

\subsection{Strong communities: Educating parents and teachers as a source of mutual respect}

Introducing change requires the education of both teachers and parents, young people and older adults, as well as understanding and mutual trust. The interviewees mentioned the examples of good practice of study circles and parent schools that promote social capital in the local environment. Transformations will be accepted if people are convinced that they are beneficial to their quality of life, hence dialogue-based learning is used to harmonize the subjective theories, beliefs and values of teachers and parents. In Slovenia, parent schools (in schools and preschools) are quite common as programs that assist in children's education. In addition to supporting education, they act as connecting elements. They can be run in cooperation with local adult education centers or various societies (pedagogical societies, rural women's associations, Caritas). When it comes to organizing parent schools, it is important to make sure that the parenteducator relationship is not one of power or superiority. Parent schools can also be linked to study circles or ecoliteracy development programs, and can work with societies for the protection of natural and cultural heritage. All of this combined constitutes the emergent networks of actors in the field of learning. All emergent networks exist in a dynamic balance, and parents and preschool teachers maintain them because they are beneficial to both sides and, even more so, to their children and families.

Personal interaction and communication are two means of influencing the changing of behavior. It is necessary to find common goals shared by different individuals and groups. An example deserving of note is a parent school [interview 6] held at a preschool - as part of it, the parents and preschool teachers set some action goals that led to the search for appropriate 
knowledge and skills depending on the goals. One of the goals was to use scraps of fabric to sew toys for children. This was the parents' contribution to the common good, which is part of community well-being. Learning about the $3 \mathrm{R}$ (repair, reuse, recycle) concept was only one part of the education, which also included learning about sewing, dyes and material processing, as well as participants' socializing and getting to know one another. Toys made of scraps of fabric were given to children as Christmas presents. The participants' conversations contributed to the formation of new views and behaviors. One of the mothers - all participants were mothers - who attended the workshops said the following in an interview:

I hadn't expected us to bond quite as much as we did. At first, it all felt like a bit of a nuisance. I'd decided to take part in it because of M. [her daughter's name, authors' note], so others wouldn't think I didn't want to participate. And then we got together on a regular basis and did some sewing and chatted [laughter]. We had quite a good time. And then we started applying these reuse ideas when it came to our own clothes too. I think all of us started giving a bit more thought to what we buy. [Interview 4]

The mothers in the group bonded and, judging by the above statement, the sense of belonging and commitment increased. Belonging, trust and support are the feelings that contribute to the satisfaction in a neighborhood. Anderson and Baldwin (2017) referred to them as neighborhood feelings. In addition to shared emotions, transformative learning, which results in a changed way of thinking and acting, can also be perceived (as may be noted in the above statement about reuse). Such forms of organized education are thus appropriate in communities where people want to work together on changing the attitude towards the environment. It is children who connect (common goals are developed) and lead to a dialogue between teachers, parents and grandparents, as well as to mutual respect. When it comes to bringing about change and transformative learning (Taylor, 2017), an important role is played by social connections and social networks, as well as by social learning.

\subsection{Intergenerational contact zones: Innovative practices}

The interviews revealed a number of examples of good practice. A common feature was the cooperation among different partners, which makes intergenerational education for sustainable development similar to intercultural education.

We no longer do projects that only involve visiting one another. We prefer projects where we can do something together. The best kinds of projects are those that involve physical activity, cooking, and singing. You have to connect people in a certain place, through an activity, so they look forward to it and so they have a good time. [Interview 7]

Projects involve the cooperation of different generations of children, as well as that between children and adults (parents, grandparents). An example of this is a project titled Produce Swap (Zelemenjava), which is participated in by parents, grandparents and children in a local environment. Another example of good practice is adults connecting with preschools and schools in preparing a safe route to school (Active travel to school, 2019). The so-called "walking bus" and "bike train" are organized campaigns where children are accompanied to preschool/school. In organizing a route to school/preschool, grandparents and parents connect with preschools and schools, which is not only a case of social cooperation and connections, but also habit (trans)formation.

Intergenerational interaction may involve a higher or lower level of contact. If the only thing that happens is children meeting older adults (e.g., when children from a preschool visit nursing home residents), this is an example of a low level of contact. Higher levels of contact occur in longer-lasting intergenerational programs, such as participants creating art or gardening together. Such activities are reflected throughout the community and various stereotypes are 
challenged. Shared gardens that are tended by children, teachers and grandparents are examples of good practice.

Intergenerational cooperation in a local community takes into account diversity. Each person has their own talent, which is not sufficiently developed by standardized programs, as such programs are constrained by the beliefs and knowledge of planners (who are not familiar with local knowledge and local culture). Multiple intelligence and socio-emotional knowledge is much more pronounced in various intergenerational projects where individuals learn in situ. Two important dimensions can be highlighted: creativity and connectivity. In the projects mentioned by the interviewees, the children worked with adults on, for instance, planting trees. The Anbot society in Piran cooperated with the Little Sailor (Mornarček) preschool from the same town and, on Earth Day (22 April), they planted some trees together. Another event organized by the society's members is a children's herb workshops titled 'Bay Leaf'. Since the society's seat in the town of Piran is located in a street named after Oton Župančič (a famed Slovenian poet), they also organize get-togethers for children on Župančič' birthday (23 January). As part of this, they invite children to workshops on selected poems by Župančič and also cooperate with the local library. The society president said the following:

It's important to set an example, an example of community cooperation. Sustainable development can only take place if we are connected. All societies, preschools, and schools need to work together. You can't do anything by yourself. I believe that you can only change something if you develop a good relationship together. I always ask myself what we all [this was emphasized by the interviewee] need. You can't shut yourself off. When all of us are together, adults and children, you commit people to your memory. You commit a relationship and a person to memory. And then you are able to remember it all. You move on from this deeply felt relationship and keep searching. [Interview 2]

In addition to the content, relationships, the transfer of tacit knowledge and getting a sense of one another, embodied and embedded knowledge are all important parts of intergenerational learning. In community education for sustainable development, it is essential to learn about and interpret the values that are immanent in groups and communities, and that are expressed in the way of life. Individuals are in a relationship with the community, with society (and the state) through social networks through which social and cultural capital is generated, as confirmed by Kaplan, Thang, Sanchez and Hoffman (2020). Intergenerational cooperation either happens or does not (if there is no one to encourage it), therefore, it is important for the community to form contact zones for meetings. In community education, transformative learning also includes affective and activity elements. Knowledge formation takes place through "ways-ofknowing-in-being". An important part of this is the environment, i.e., the place and the nature where an individual or a group live. Viewing learning in this particular way attaches great importance to groups and learning spaces (forests, meadows, streams) with which people in the local community can identify. The older generation transfers the identification and the care of this space to the younger generation.

\section{Conclusion}

The research participants, who all had previous experience with intergenerational projects, expressed positive opinions about intergenerational education, which they view as a new opportunity for community-based environmental learning and education. This suggests an urgent need for cross-sectoral and inter-institutional connections and interagency. The research participants believe that it is necessary to organize intergenerational contact zones, where young people and older adults can meet and work together. 
The local community as a whole (people, space/place, ways of thinking and feeling, memories, stories) is becoming crucial for intergenerational cooperation, the formation of learning ecologies and for the development of ecological awareness. Educational organizations, NGOs and families play an important part. New cooperation strategies are part of postformal education. It has been established that preschools can be part of community education and contribute to transformative learning in the local environment. It has also been established that the following is important for the process of preschools' connection with community education to create learning ecologies: (a) connecting different types of knowledge (intangible cultural heritage, local and scientific knowledge, practical wisdom) with emotional attachment across generations (socio-emotional intelligence, affective attachment), (b) connecting various organizations (preschools, schools, universities of the third age, societies, libraries, museums).

The contribution of preschools, schools, universities of the third age to community education models is important as cohesive communities are more resilient to global pressures. As positive emotions (connectedness, support, respect, commitment to the common good) are cultivated in the community, community well-being is developed. Cooperativeness and empathy are developed through experiencing cooperativeness and empathy. Stronger feelings of belonging to the community, changes to community life, solidarity and anti-individualism develop in learning ecologies where all generations are involved.

Sustainable development and the related community well-being are an ethical issue, and one of transformation of consciousness and activity. Therefore, all organizations and generations need to be integrated into common networks, which imply educational programs that will be inclusive, and will animate the development of new practices. The community and its capacity for change is at the core of the changes for a sustainable future.

\section{Acknowledgements}

This research did not receive any specific grant from funding agencies in the public commercial, or not-for-profit sectors.

The authors declare no competing interests.

\section{References}

Active travel to school (2019). Retrieved 15 July 2019, from https://www.aktivnovsolo.si/vrtci-in-osvabljeni-da-se-prikljucite-projektu-trajnostna-mobilnost-v-vrtcih-in-os/.

Anderson, R. E. (2017). Community functioning that fosters sustainable social well-being. In R. Philips \& C. Wong (Eds.), Handbook of community well-being research (pp. 3-10). Dordrecht: Springer.

Anderson, J., \& Baldwin, C. (2017). Building well-being: Neighbourhood flourishing and approaches for participatory urban design intervention. In R. Philips \& C. Wong (Eds.), Handbook of community well-being research (pp. 313-337). Dordrecht: Springer.

Azeiteiro, U., Leal, F., \& Aires, L. (Eds.). (2018). Climate literacy and innovations in climate change education. Distance learning for sustainable development. Cham: Springer.

Barnett, R., \& Jackson, N. (Eds.) (2020). Ecologies for learning and practice. New York: Routledge.

Braidotti, R. (2013). The nosthuman. Cambridge: Polity Press.

Braidotti, R., \& Bigual, S. (Eds.). (2018). Posthuman ecologies. Complexity and process after Deleuze. London: Rowman \& Littefield. 
Clover, D., Jayme, B., Hall, B., \& Follen, S. (2013). The nature of transformation. Rotterdam: Sense.

Creswell, J. W., \& Plano Clark, V. L. (2017). Designing and conducting mixed methods research. London: Sage.

Engdahl, I. (2015). Early childhood education for sustainability: The OMEP world project. IJEC International Journal of Early Childhood, 47, 347-366.

Fazey, I. (2017). Community resilience to climate change. Dundee: University of Dundee.

Fenwick, T., \& Edwards, R. (Eds.) (2017). Revisiting actor-network theory in education. New York: Routledge.

Flick, U. (2019). An introduction to qualitative research. $6^{\text {th }}$ ed. London: Sage.

Gidley, J. (2016). Postformal education: A philosophy for complex futures. Cham: Springer.

Guattari, F. (2000 [1989]). The three ecologies. London: The Athlone Press.

Häggström, M. (2017). An aesthetic and ethical perspective on art-based environmental education and sustainability from a phenomenological viewpoint. In O. Franck \& C. Osbeck (Eds.), Ethical literacies and education for sustainable development. Young people, subjectivity and democratic participation (pp. 85-104). Cham: Palgrave MacMillan. https://doi.org/10.1007/978-3-319-49010-6_6

Higgins, M. (2016). Decolonizing school science: Pedagogically enacting agential literacy and ecologies of relationship. In C. Taylor \& C. Huges (Eds.), Posthuman research practices (pp. 267-289). Basingstoke: Palgrave Macmillan. https://doi.org/10.1057/9781137453082 12

Jubas, K., \& Lenters, K. (2019). Extemporaneous lesson on place, space, and identity: Graffiti as a pedagogical disruption. Engaged Scholar Journal: Community-Engaged Research, Teaching and Learning , 5(2), 79-94. https://doi.org/10.15402/esj.v5i2.68336

Kaplan, M., Sanchez, H., \& Hoffman, J. (2017). Intergenerational pathways to a sustainable society. Cham: Springer.

Kaplan, M., Thang, L. L., Sanchez, M., \& Hoffman, J. (2020). Intergenerational contact zones. New York: Routledge.

Latouche, S. (2018). The misadventures of the good life between modernity. In H. Rosa \& C. Henning (Eds.), The good life beyond growth. New York: Routledge.

Lee, S. J., Kim, Y., \& Philips, R. (2015). Community well-being and community development. Dordrecht: Springer.

Martinez, J., Verplanke, J., \& Miscione, G. (2017). A geographic and mixed methods approach to capture unequal quality-of-life conditions. In R. Philips \& C. Wong (Eds.), Handbook of community well-being research (pp. 385-402). Dordrecht: Springer.

Open learning Environment for All Generations project (2019). Retrieved 17 August 2019, from http://vrtec-konjice.si/?p=5817; https://www.zgodovinska-mesta.si/wpcontent/uploads/2019/05/ODPRTO-U\%C4\%8CNO-OKOLJE-ZA-VSE-GENERACIJEKratek-opis-projekta.pdf.

Philips, R., \& Wong, C. (Eds). (2017). Handbook of community well-being research. Dordrecht: Springer.

Röttger-Rössler, B., \& Slaby, J. (2018). Affect in relation. London: Routledge.

Smith, T. S. (2019). Sustainability, wellbeing and the posthuman turn. Cham: Palgrave Macmillan, Springer.

Stoknes, P. E. (2015). What we think about when we try not to think about global warming. White River Junction: Chelsea Green Publishing.

Taylor, E. W. (2017). Transformative learning theory. In A. Laros, T. Fuhr \& E. W. Taylor (Eds.), Transformative learning meets buildung (pp. 17-29). Rotterdam: Sense. 
N. Ličen et al. - Intergenerational Education to Enhance Sustainable Community Development

Taylor, C. A., \& Hughes, C. (Eds.) (2016). Posthuman research practices in education. New York: Palgrave Macmillan.

Weldemariam, K. (2017). Challenging and expanding the notion of sustainability within early childhood education: Perspectives from post-humanism and/or new materialism. In O. Franck \& C. Osbeck (Eds.), Ethical literacies and education for sustainable development. Young people, subjectivity and democratic participation (pp. 105-126). Cham: Palgrave MacMillan.

Yamagata-Lynch, L. C. (2010). Activity systems analysis methods. New York: Springer.

Yin, R. K. (2018). Case study research and application. London: Sage. 